\title{
Effects of temperature and salinity on the larval development of the Chinese mitten crab Eriocheir sinensis (Decapoda: Grapsidae)
}

\author{
K. Anger \\ Biologische Anstalt Helgoland, Meeresstation, W-2192 Helgoland, Germany
}

\begin{abstract}
Larvae of the Chinese mitten crab Eriocheir sinensis H. Milne-Edwards were reared in the laboratory under 25 different combinations of constant temperature $\left(6\right.$ to $\left.18{ }^{\circ} \mathrm{C}\right)$ and salinity $(10$ to $32 \%$ S). Different schedules of changing salinity were tested only in the final larval stage, the megalopa. Pelagic larval development comprises a total of 5 zoeal stages and 1 megalopa. An additional (stage VI) zoea and in one case an additional megalopa (transitional to the juvenile) were occasionally observed under unfavourable conditions with low salinity $(\leq 15 \% \mathrm{~S})$. Successful development from hatching to metamorphosis occurred only at temperatures $\geq 12^{\circ} \mathrm{C}$. With increasing temperature, both overall survival and range of salinity tolerance increased, whereas development duration decreased exponentially. Regression equations describing this relationship are given for different larval stages and salinities. Development time increased at unfavourably low or high salinities (i.e. where mortality also increased). Zoea I was very euryhaline, with an optimum in slightly brackish water $(25 \%$ S). During subsequent zoeal development, the larvae became increasingly stenohaline, and their optimum shifted to seawater The megalopa, in contrast, was euryhaline again and developed fastest in lower salinities (15 to $25 \% \mathrm{~S}$ ). When larvae were reared in seawater until they reached the megalopa stage and then transferred to lower salinities, development to the first juvenile instar was also possible at $\leq 5 \% \mathrm{~S}$, exceptionally even in freshwater Thus, metamorphosis of E. sinensis is, after a gradual adaptation during megalopa development, possible in principle at any salinity. An optimum, however, was found in the range from 15 to $25 \% \mathrm{~S}$. These patterns of ontogenetic change in salinity tolerance are interpreted as an adaptation to patterns of larval dispersal presumably occurring in the field: (1) hatching in brackish water of outer estuaries; (2) offshore (near-surface) transport during zoeal development, with late stages living predominantly under marine conditions; (3) onshore (near-bottom) transport of the megalopa; (4) settlement in any part of an estuary, probably most frequently at ca 15 to $25 \% \mathrm{~S}$.
\end{abstract}

\section{INTRODUCTION}

The mitten crab Eriocheir sinensis was introduced early this century from China into German rivers (Peters \& Panning 1933), from where it spread over great parts of Europe, including Holland (Otto \& Kamps 1935), Belgium (Leloup 1943), France (Hoestland 1959), Czechoslovakia (Panning 1938), Denmark (Jensen 1936), Finland and Sweden (Haahtela 1963). In the 1920 's, E. sinensis became so abundant in Germany that it was considered a harmful pest and fish predator (Peters 1936, Thiel 1936), and many scientific and other publications discussed possibilities of its control and commercial exploitation (Werner \& Schmalfuß 1936). Its present distribution in Europe ranges from the Bay of Biscay (France) to the northernmost and easternmost parts of the Baltic Sea, including Russian and Polish waters (Christiansen 1982). It has been observed only a few times in England (Ingle \& Andrews 1976), Norway (Christiansen 1977), and North America (Nepszy \& Leach 1973). In China it is now considered a candidate for commercial aquaculture (Lee \& Yamazaki 1989) and thus, the development of cultivation methods is important.

Juvenile mitten crabs can migrate up to ca $1000 \mathrm{~km}$ upstream while growing to adult size (Schellenberg 1928). Sexually mature individuals migrate back downstream to reproduce. Their larvae hatch in spring and early summer, probably in lower parts of estuaries (Panning 1938).

Very little is known about development, morphology, and environmental requirements of mitten crab larvae, including the number of developmental stages. Schnakenbeck (1933) gave a rough description of the 
prezoea, zoea I, and megalopa. Panning (1936a) suggested the existence of 4 zoeal stages, and considered assumed ontogenetic migrations in estuarine and nearby coastal regions (Panning 1936b). Hinrichs \& Grell (1937) found a few late zoeae and one megalopa near Helgoland in the North Sea, ca $60 \mathrm{~km}$ off the coast. They presumed that these larvae had drifted too far from the Elbe estuary into the open sea and therefore would not have a realistic chance of further development and survival.

Buhk (1938) was the first to successfully rear Eriocheir sinensis larvae in an aquarium. He suggested the existence of 5 zoeal stages. His material was analysed by Panning (1939), who described the morpholagy of only 4 zoeal stages, without giving sufficient details.

In the present investigation, Eriocheir sinensis larvae were reared for the first time under controlled conditions in the laboratory in order to study their survival and development in relation to the environmental factors of temperature and salinity. These experimental data were analyzed for possible developmental changes in larval tolerance, because such changes could indicate genetic adaptations to ontogenetic migrations in estuarine and coastal marine regions. This would provide information on where E. sinensis is able to pass its pelagic phase of development in the field, where the megalopa can settle and undergo metamorphosis, and how fast this larval stage may be able to invade estuaries and river systems.

\section{MATERIALS AND METHODS}

Ovigerous female mitten crabs were dredged in February and March 1989 from the outer Elbe estuary, from ca 10 to $15 \mathrm{~m}$ depth, between the islands of Neuwerk and Scharhörn. They were transported in aquaria with brackish water (ca 20 to $22 \%$ S) from the site of capture to the Marine Biological Station, Helgoland, where they were maintained in recirculating systems with the same salinity and a constant $12{ }^{\circ} \mathrm{C}$.

In many females the eggs were infected by fungi. Low numbers of larvae (mostly also infected) hatched from those egg masses, beginning in late March. The first viable larvae hatched in May. Actively swimming larvae were transferred with wide-bore pipettes to numbered cultivation vials $\left(30 \mathrm{~cm}^{3}\right)$. In each of 25 combinations of temperature and salinity, 25 larvae were reared individually. The following salinities were tested: $10,15,20,25$, and $32 \%$ S (average salinity of seawater near Helgoland), Lower salinities were obtained by dilution of filtered $(1 \mu \mathrm{m})$ seawater with tap water (desalinated seawater). Temperatures tested were $6,9,12,15$, and $18^{\circ} \mathrm{C}$, i.e. the full range normally occurring during spring and summer near Helgoland. Water and food (freshly hatched San Francisco Bay Brand $^{\text {TM }}$ Artemia sp. nauplii) were changed daily (at temperatures $\geq 12{ }^{\circ} \mathrm{C}$ ) or every second day $\left(\leq 9^{\circ} \mathrm{C}\right)$.

Another part of the hatch was mass-reared in glass bowls $\left(400 \mathrm{~cm}^{3}\right)$ at $32 \% \mathrm{~S}$ and constant $15^{\circ} \mathrm{C}$, with an initial number of 60 larvae per bowl. Water and food (as above) were changed daily. One part of these larvae was used for morphological studies (to be presented elsewhere), another part for additional experiments with the megalopa. Since this stage is presumed to invade estuaries and rivers (Panning 1939), its tolerance to lowered salinites was tested separately. For this purpose, a total of 100 freshly moulted megalopa larvae were transferred from mass cultures to individual rearing bowls $\left(50 \mathrm{~cm}^{3}\right)$ with salinities of $25,20,15$, and $10 \% \mathrm{~S}$ ( 25 individuals per condition). Those to be reared at $\leq 20 \% \mathrm{~S}$ were gradually acclimatized to lower salinities, in steps of $5 \% \mathrm{~S}$ decrease each $3 \mathrm{~h}$. In another experiment, upstream migrations presumed to occur in the field (Panning 1936b) were simulated: 50 megalopa larvae were split into 2 groups (also reared individually). Salinity was lowered from 32 to $25 \% \mathrm{~S} 3$ or $4 \mathrm{~d}$ after moulting, and then every 3 or $4 \mathrm{~d}$ by another $5 \% \mathrm{~S}$. Before transferring the larvae from $5 \% \mathrm{~S}$ to freshwater, an additional step ( 3 or 4 d) was made at $2 \%$ S. Hence, development took place here under increasingly brackish conditions and eventually in freshwater. All these experiments with megalopa were conducted at constant $15^{\circ} \mathrm{C}$. Water and food were changed daily (as above).

Statistical comparison of mean values with equal or unequal variances (after an $F$-test) was carried out using the appropriate $t$-statistics (Sachs 1984, p. 212-214).

\section{RESULTS}

\section{Development and survival}

In the laboratory, Eriocheir sinensis larvae developed normally through a brief, non-feeding prezoea, 5 zoeal stages, and a megalopa. Under very unfavourable conditions (see below), a sixth zoeal stage occurred, and in one case an additional megalopa stage was observed.

Mitten crab larvae were able to develop from hatching through metamorphosis at temperatures ranging from 12 to $18{ }^{\circ} \mathrm{C}$ and at salinities from 15 to $32 \% \mathrm{~S}$, but not in all combinations of these conditions (Fig. 1). At 6 and $9{ }^{\circ} \mathrm{C}$ (any salinity), complete mortality occurred within the first zoeal stage, with longest time of survival in intermediate salinities (20 to $25 \% \mathrm{~S}$ ). Rate or time, respectively, of larval survival increased at all salinities with increasing temperature (Figs. 1 \& 2). At tem- 

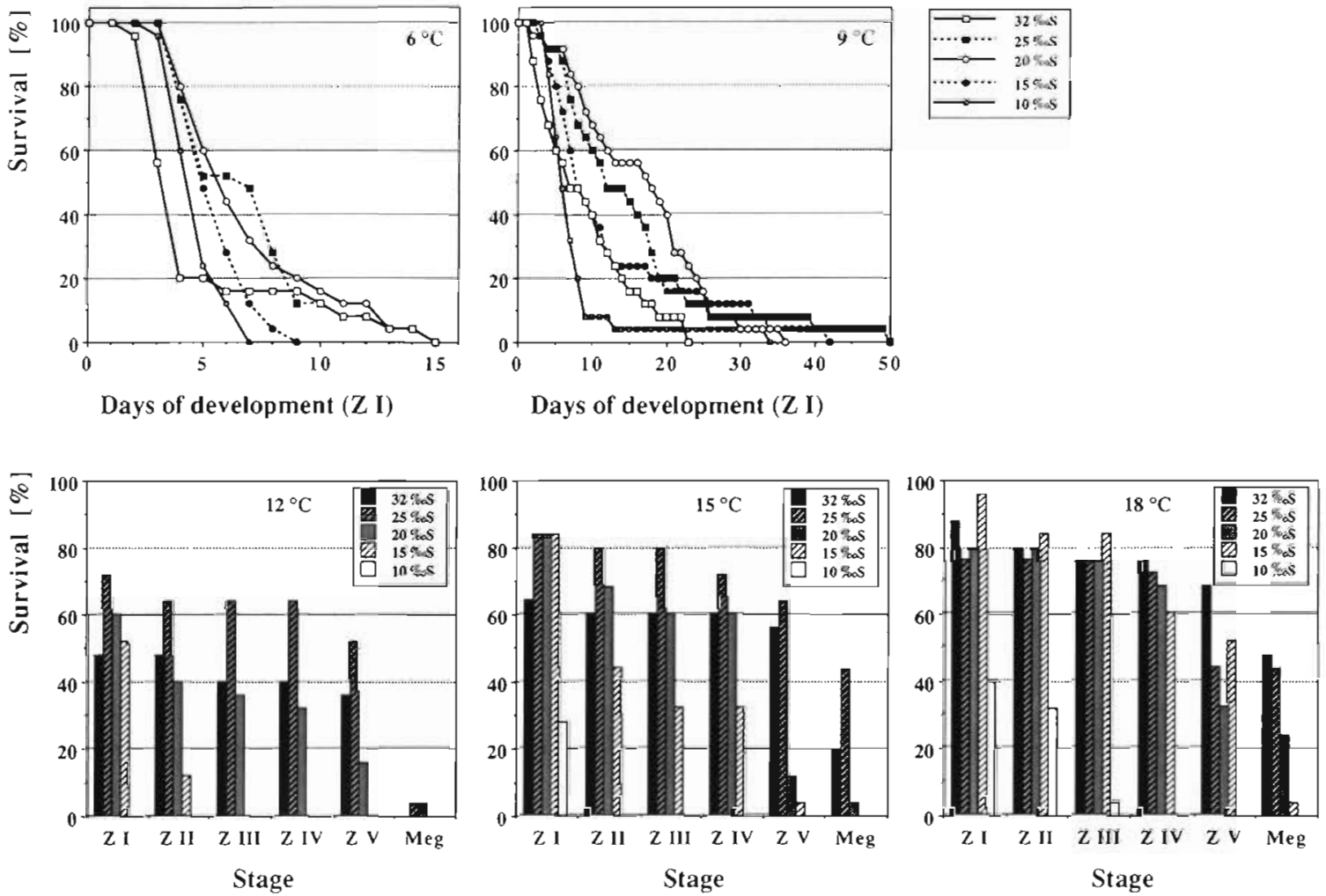

Fig. 1. Eriocheir sinensis. Survival (cumulative \%; initial $\mathrm{n}=25$ ) of larval stages in relation to temperature $\left({ }^{\circ} \mathrm{C}\right)$ and salinity $(\% \mathrm{~S})$;

Z: zoeal stages, Meg: megalopa

peratures $\leq 12{ }^{\circ} \mathrm{C}, 10 \%$ S allowed no development beyond the zoea I stage, but in combination with $15^{\circ} \mathrm{C}$ to zoea II, and with $18^{\circ} \mathrm{C}$ to zoea IV. At a salinity of $15 \%$ S, only the zoea III stage was reached at $12{ }^{\circ} \mathrm{C}$, but the megalopa at $15^{\circ} \mathrm{C}$, and metamorphosis to the first juvenile stage at $18^{\circ} \mathrm{C}$. These data (Fig. 1) show clearly that not only the average level of survival but also the range of salinity tolerance increased with increasing temperature.

A combination of $15^{\circ} \mathrm{C}$ with $15 \% \mathrm{~S}$ was unfavourable and caused not only high mortality but also a developmental abnormality: 8 individuals (32\%) successfully reached the zoea $V$ stage, but none of them was able to develop to the megalopa directly. Instead, 5 of them moulted to a zoea VI stage (the others died). Only one of these extra stages developed successfully to the megalopa, but this one also died later.

Cumulative survival of the zoeal stages at lower temperatures $\left(12,15^{\circ} \mathrm{C}\right)$ was consistently maximal at a slightly reduced salinity $(25 \% \mathrm{~S}$; Fig. 1). At higher temperature $\left(18^{\circ} \mathrm{C}\right)$, survival was initially maximal at a lower salinity $(15 \% \mathrm{~S})$. However, later during zoeal development this optimum shifted towards seawater (Fig. 1). These patterns show that both temperature and stage of development exert strong influences on salinity tolerance of mitten crab larvae.

Changes in salinity tolerance during larval develop- ment may be more easily recognizable when mortality in each stage is considered separately, concentrating only on the 3 most suitable (i.e. highest) temperatures and salinities (Fig. 2). In general, enhanced mortality occurred at the beginning (zoea I) and again near the end (in the megalopa stage) of larval development. Both the first and the last stage appeared particularly sensitive to a combination of high salinity $(32 \% \mathrm{~S})$ with low temperature $\left(\leq 15^{\circ} \mathrm{C}\right)$, and both stages showed highest survival rates in slightly brackish water (20 or $25 \%$ S). In contrast, the late zoeal stages (zoea IV, V) showed consistently best survival in seawater and a decreased tolerance to brackish water (Fig. 2). As a consequence of these patterns, the highest number of larvae reached the megalopa stage at $25 \% \mathrm{~S}(12$ and $15^{\circ} \mathrm{C}$ ) or at $32 \% \mathrm{~S}\left(18^{\circ} \mathrm{C}\right)$ (Fig. 1). Thereafter, lowest mortality occurred in combinations of high temperature and slightly reduced salinity $\left(15\right.$ to $\left.18^{\circ} \mathrm{C}, 25 \% \mathrm{~S}\right)$, and in colder water $\left(12{ }^{\circ} \mathrm{C}\right)$ with lower salinity $(20 \%$ S $)$.

Only very few larvae survived to the megalopa stage at constant $15^{\circ} \mathrm{C}$ and salinities $\leq 20 \%$ S (Fig. 1). However, when larvae were reared at the same temperature, but in seawater $(32 \% \mathrm{~S})$ until reaching the megalopa stage, and were then transferred to lower salinities, they exhibited a greater tolerance to brackish water. Maximum survival to metamorphosis occurred also here at $25 \%$ S, but high rates were also observed at 

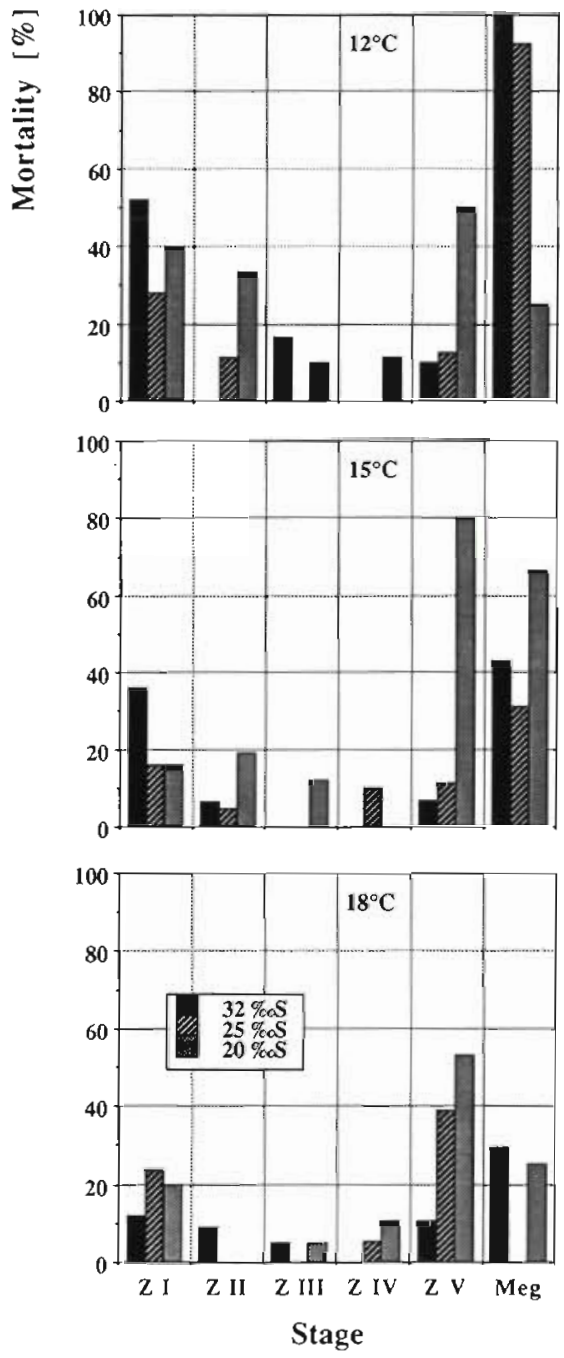

Fig. 2. Eriocheir sinensis. Mortality in larval stages (\% of survivors to a given stage) in relation to temperature and salinity. For further explanations see Fig. 1

20 and $15 \%$ S. Much lower survival was found in seawater and at $10 \% \mathrm{~S}$ (Fig. 3, upper graph).

When salinity was lowered stepwise every $3 \mathrm{~d}$ during megalopa development, none of the larvae reached the first juvenile stage. A few survived up to 24 d, i.e. they lived for some time even in freshwater, but no metamorphosis then occurred. In larvae that were transferred to lower salinities only every $4 \mathrm{~d}$, one individual moulted after 20 d (at $5 \%$ S) to an intermediate stage between megalopa and juvenile (morphologically still more similar to a megalopa; this individual died the next day), and another 2 metamorphosed the same day successfully to the first crab stage. A fourth megalopa became a juvenile after 26 d (at $2 \%$ S). Two of the 3 surviving crabs died later, in the first and second instar, respectively (both in freshwater), whereas one was still living in freshwater after more than $11 / 2 \mathrm{yr}$
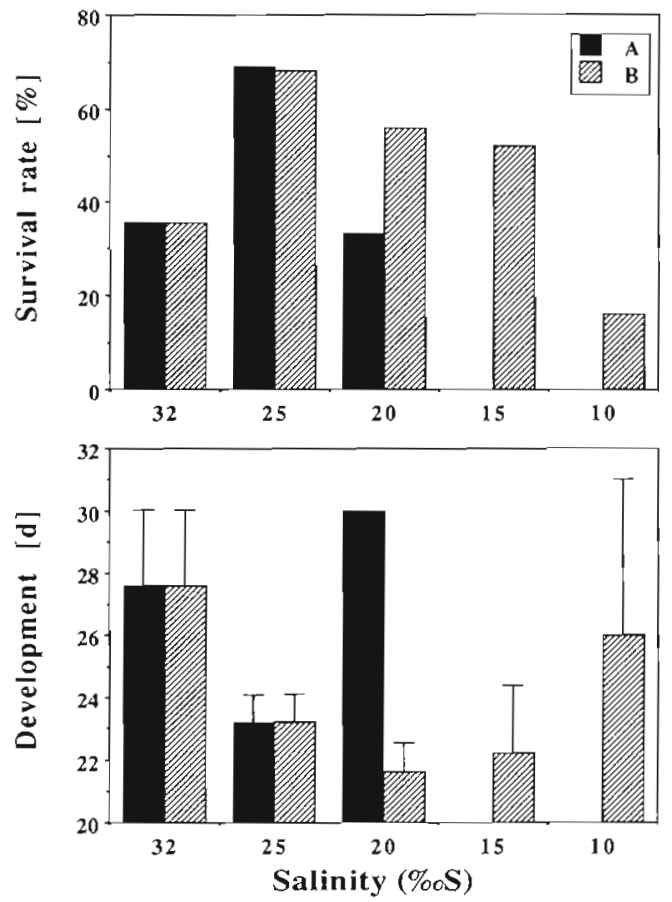

Fig. 3. Eriocheir sinensis megalopa. Survival $(\%)$ and duration of development ( $d ; \bar{x} \pm 95 \%$ confidence intervals) at different salinities $\left(\%\right.$ S) and constant $15^{\circ} \mathrm{C}$. A: constant salinities since hatching of zoea I; B: rearing of zoeal stages at $32 \%$ S, larvae exposed to other salinities only after reaching the megalopa stage. Materials in A and B hatched the same day from the same mother (sibling larvae)

In a preliminary experiment, where larvae were reared at $25 \% \mathrm{~S}$, and salinity was gradually reduced during megalopa development, 2 individuals metamorphosed successfully to the first juvenile stage in freshwater. This shows that metamorphosis is in principle possible under any condition (marine, brackish, or freshwater), provided there is a gradual adaptation to decreasing salinity during megalopa development.

\section{Duration of development}

The time of development $[D$, in days $(d)]$ was in all larval stages much more influenced by temperature than by salinity (Fig. 4). In all stages and experimental conditions, where at least 3 mean values of $D$ had been obtained, it could be expressed as an exponential function of temperature $\left(T\right.$, in $\left.{ }^{\circ} \mathrm{C}\right)$. The regression equations describing this relationship in different salinities and larval stages are given in Fig. 4. High correlation coefficients ( $r$; all values $\geq|0.997|$ are significantly different from zero) indicate that $T$ is a strong determinant of $D$.

Development in most stages showed a significant delay in unsuitably low salinities (Fig. 4; error bars are $95 \%$ confidence intervals). In the zoea I and megalopa, 

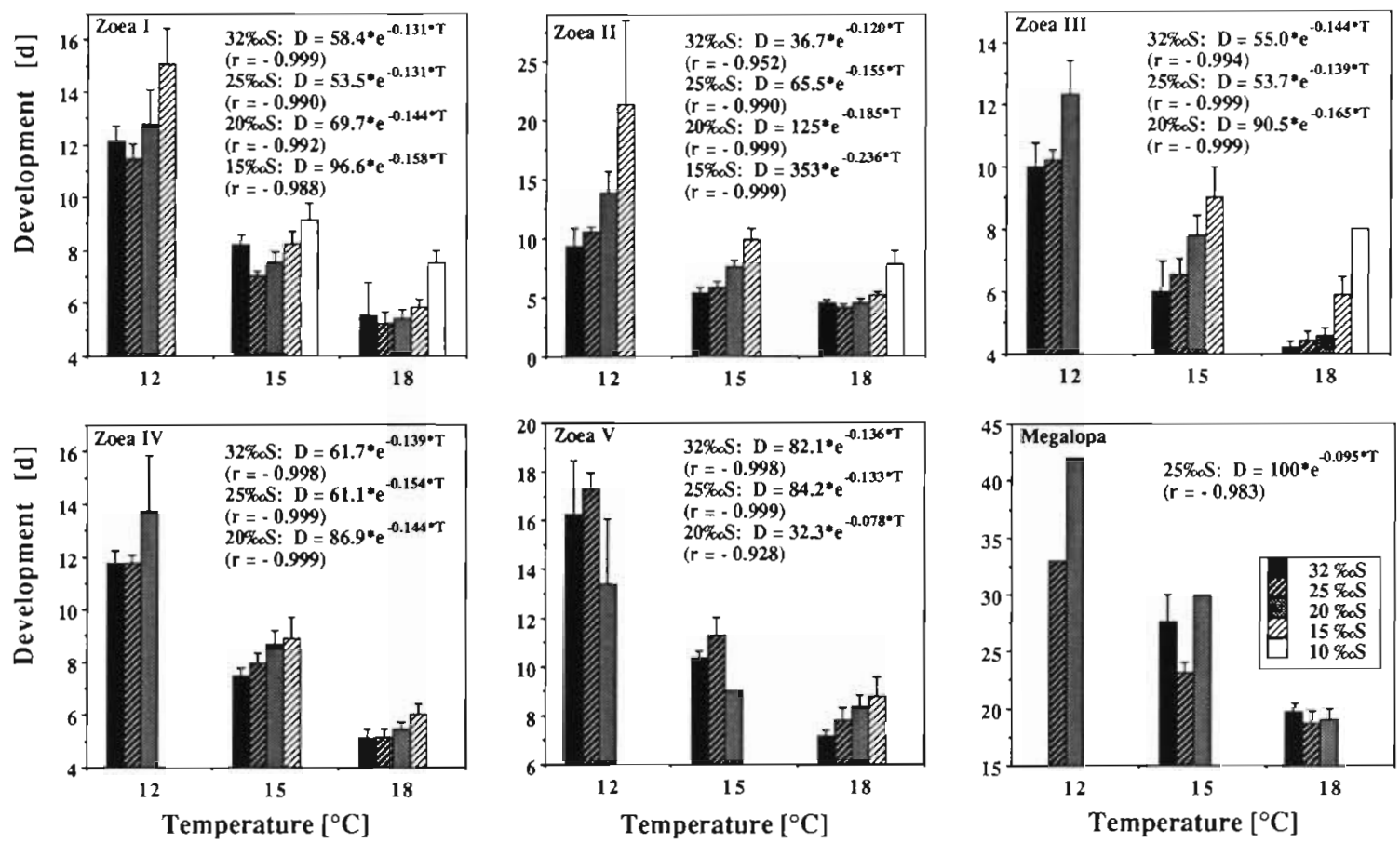

Fig. 4. Eriocheir sinensis. Duration of development $(D$, in $\mathrm{d} ; \overline{\mathrm{x}} \pm 95 \%$ confidence intervals) in larval stages in relation to temperature $\left(T_{;}{ }^{\circ} \mathrm{C}\right)$ and salinity $(\% \mathrm{~S})$. Exponential regression equations describe $D$ as a function of $T$; r: correlation coefficient

delays (statistically not significant) occurred also in seawater. A salinity of $25 \%$ S appeared to be the optimum in these 2 stages, as may also be concluded from mortality figures (Figs. 1 \& 2). In the zoea $V, D$ was shorter at $20 \% \mathrm{~S}$ as compared to higher salinities (Fig. 4). Due to low survival, however, this effect was statistically not significant.

When $D$ is considered in megalopa larvae that were exposed to different salinities only after developing in seawater to this stage, a clear shift in their salinity optimum may be seen: shortest development was in the range 15 to $25 \%$ S, with minimum $D$ at $20 \%$ S (Fig. 3 , lower graph). When the megalopa remained in seawater $(32 \% \mathrm{~S})$, development to metamorphosis was significantly prolonged. A delay occurred also at $10 \% \mathrm{~S}$ (statistically not significant, due to the low number of survivors). These findings not only corroborate the above conclusion that the ultimate larval stage exhibits a greater tolerance to brackish water than late zoeal stages, but it also suggests a preference of the megalopa for intermediate salinities (15 to $25 \%$ S). even if previous development had taken place exclusively in seawater.

\section{DISCUSSION}

Larval development of Eriocheir sinensis consists normally of a prezoea, 5 zoeal stages, and a megalopa. This corrects Panning's (1936b, 1939) and confirms
Buhk's (1938) assumptions. However, unfavourable conditions (low salinity, $15 \% \mathrm{~S}$, in combination with relatively low temperature, $15^{\circ} \mathrm{C}$ ) may cause some variability in developmental pathways, with an additional zoeal stage (VI). At a stepwise decreasing salinity, in one case also an additional (transitional) megalopa stage occurred. Developmental variability has been observed also in other crab species belonging to the family Grapsidae: Cyclograpsus integer (Gore \& Scotto 1982), Aratus pisoni (Díaz \& Bevilacqua 1987), and recently in Metasesarma rubripes (Montú et al 1990). In the latter case, it occurred also under constant conditions and was related to genetic variability in larval viability (both among different hatches and among individuals from the same hatch). These observations suggest that there may be some tendency toward developmental variability in the grapsid family, since otherwise this is quite uncommon in the Brachyura (Montú et al. 1990). Such a variability may be an advantage in species that live in a highly variable, unpredictable environment (Sandifer \& Smith 1979). This is the case in most Grapsidae, where a transition from the marine to freshwater and terrestrial habitats is very common (see Anger et al. 1990 for references), and is certainly true for the Chinese mitten crab.

All larval stages of Eriocheir sinensis show a clear preference for warm water $\left(15\right.$ to $\left.18^{\circ} \mathrm{C}\right)$, whereas temperatures below $12{ }^{\circ} \mathrm{C}$ did not allow any development beyond the first zoeal stage. This sensitivity to low temperatures does not correspond with the present 
range of distribution (Christiansen 1982), nor with the time of larval hatching in Europe. Since this species originates from a temperate to subtropical region (Panning 1938), its larval response patterns may be an adaptation to the climatic conditions that prevail in the area where this species evolved. Downstream migration and reproduction (copulation, egg-laying) occur during autumn and early winter, respectively, and embryogenesis in winter and spring (Panning 1938). Unusually cold winters might thus damage the embryos and so contribute to low recruitment, or may even cause loss of single year-classes. Larvae hatching in late March and April (i.e. at temperatures of $\mathrm{ca} 4$ to $8{ }^{\circ} \mathrm{C}$, as observed by us in the laboratory) should also have very high mortality in the field. Thus, high rates of recruitment should be expected only after mild winters, and from those larvae which hatch latest in the season. This shows that $E$. sinensis is, even after ca $80 \mathrm{yr}$ of occurrence in European waters, still not fully adapted to the climatic conditions in this region.

Clear signs of developmental changes were observed in the tolerance of larval stages to varying salinity. Both survival and development duration in different salinities suggest that the zoea $I$ is a very euryhaline larval stage. When temperature is suitable (i.e. high), salinities between 10 and $>30 \%$ S are easily tolerated, although the extremes cause increases in mortality (Figs. 1 \& 2) and development time (Fig. 4). Since ovigerous females were found exclusively in the lower estuary, where salinity was ca $20 \%$ S but may vary considerably during the tidal cycle and with meteorological conditions, this euryhaline response of early mitten crab zoeae corresponds very well with the salinity regime in the area of hatching and early development. Hence, it may be interpreted as an adaptation to unstable and low salinities.

The subsequent zoeal stages show a gradually decreasing tolerance to low salinities and eventually (zoea IV, V), a clear preference for seawater. This pattern agrees well with the idea that the larvae are transported out of the estuary into the open sea, where they develop to the megalopa (Panning 1936b, 1938). Ontogenetic changes in the salinity optimum of larvae associated with their distribution in the environment have also been observed in bivalve molluscs (Yaroslaviseva et al. 1986).

The final larval stage exhibits an increased tolerance to low salinities as compared to the late zoeal stages. After a gradual acclimatization from seawater to increasingly brackish water, metamorphosis is possible at very low salinities $(\leq 5 \% \mathrm{OS})$, where zoeal stages could not survive. This pattern shows that no acclimatization due to previous rearing at high salinity $(32 \% \mathrm{~S})$ occurred here, as such an effect would have caused decreased instead of increased tolerance to lower salinities (Rosenberg \& Costlow 1979). Thus, low cumulative larval survival in brackish water (Fig. 1) was caused exclusively by great sensitivity of the late zoeal stages, whereas the megalopa showed clear signs of an increased tolerance to low salinities (Fig. 3). In the field, the megalopa was found in the North Sea (Hinrichs \& Grell 1937) as well as in all parts of the Elbe estuary, including freshwater (Schnakenbeck 1933, Panning 1936b, 1939). This suggests that metamorphosis of Eriocheir sinensis is possible anywhere between seawater and freshwater, provided that some time for acclimatization to low salinity is available during megalopa development. Panning (1936b) estimated from tidal current speeds that the megalopa could theoretically migrate into the Elbe estuary with a velocity of up to $40 \mathrm{~km} \mathrm{~d}^{-1}$. The present laboratory experiments with stepwise lowered salinites, however, show that this is not very likely, as such a rapid decrease in salinity causes high or even complete mortality.

Combined effects of temperature and salinity on larval stages of the Chinese mitten crab reared in the laboratory may be summarised as follows. In general, the larvae prefer relatively high temperatures (ca $18{ }^{\circ} \mathrm{C}$ ), while lower temperatures cause in all stages increased mortality and a decrease in the range of salinities tolerated. Although the juvenile and adult crabs live in freshwater, Eriocheir sinensis is clearly a marine species that requires brackish or marine waters for successful larval development. Such a discrepancy between environmental requirements during the larval and juvenile or adult phase of the life cycle has been found also in other grapsid crab species that originate from the sea but can inhabit freshwater or terrestrial habitats (Díaz \& Bevilacqua 1986, Anger et al. 1990, Montú et al. 1990).

The hypothetical ontogenetic migrations in Eriocheir sinensis are summarised in a schematic diagram (Fig. 5). It assumes hatching of the prezoea and zoea I in lower estuaries, at salinities around 20 (ca 10 to 25 ) \% S. Since early zoea larvae are mostly found near the water surface, due to certain behavioural responses to light, gravity, pressure and other factors (Sulkin 1984, Forward \& Buswell 1989), they are likely to be transported by surface currents that have a net direction out of the estuary. Later zoeal development then takes place at increasing salinities in nearshore marine waters. The megalopa stage attains, like in all brachyuran decapods, an increasingly benthic behaviour, eventually leading to settlement on the sea floor. Since it still exhibits frequent swimming activity, it will be transported by onshore-directed, near-bottom counter currents toward the coast and inner parts of estuaries. After metamorphosis, the juvenile crab may stay in this environment for some time (maybe $1 \mathrm{yr}$; Panning 1938), 


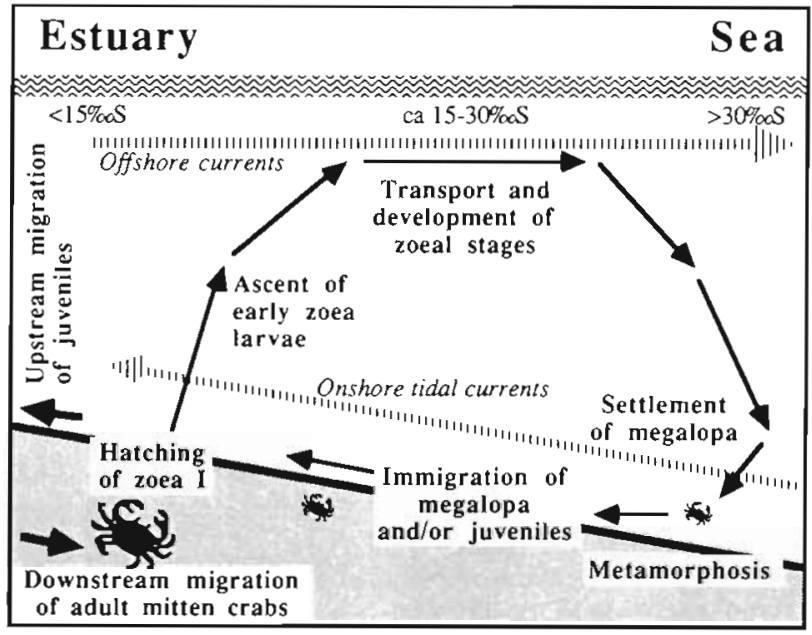

Fig. 5. Eriocheir sinensis. Graphical model of presumable ontogenetic migrations during reproduction, larval development, settlement, and early juvenile growth in an estuary and the adjacent sea (Elbe, North Sea)

or it may immediately begin to migrate upstream into river systems. This sequence of developmental changes in larval behaviour and salinity tolerance may ensure the retention of this species near estuaries and its return to freshwater habitats. Similar retention mechanisms have been found also in other estuarine crab species (Sulkin \& van Heukelem 1982, Sulkin \& Epifanio 1986; for recent discussion see Epifanio et al. 1989).

The Chinese mitten crab represents one of the most extreme cases of transitions from marine to freshwater habitats. This fact has made the adults a frequently used object of studies in comparative physiology and biochemistry (e.g. Bianchini \& Gilles 1990). Since it shows different physiological adaptations during different phases of its life cycle, its larvae and juveniles could in future studies offer a suitable model of ontogenetic and thus presumably evolutionary patterns in such adaptations.

Acknowledgements. I thank Ms. B. Wilmes for technical assistance in the experiments and the crew of RV 'Aade' for providing mitten crabs.

\section{LITERATURE CITED}

Anger, K., Harms, J., Montú, M., de Bakker, C. (1990). Effects of salinity on the larval development of a semiterrestrial tropical crab, Sesarma angustipes (Decapoda: Grapsidae). Mar. Ecol. Prog. Ser 62: 89-94

Bianchini, A., Gilles, R. (1990). Cyclic AMP as a modulator of $\mathrm{NaCl}$ transport in gills of the euryhaline Chinese crab Eriocheir sinensis. Mar. Biol. 104: 191-195

Buhk, F. (1938). Zur Fortpflanzungsbiologie der Wollhandkrabbe. Wschr. Aquar. Terrarienk. 35: 776-780
Christiansen, M. E. (1977). Kinesisk ullhåndkrabbe funnet for første gang i Norge. Fauna 30: 134-138

Christiansen, M. E. (1982). A review of the distribution of Crustacea Decapoda Brachyura in the Northeast Atlantic. Quad. Lab. Tecnol. Pesca 3: 347-354

Diaz, H., Bevilacqua, M. (1986). Larval development of Aratus pisonii (Milne Edwards) (Brachyura, Grapsidae) from marine and estuarine environments reared under different salinity conditions. J coast. Res. 2: 43-49

Díaz, H., Bevilacqua, M. (1987). Early developmental sequences of Aratus pisonii (H. Milne Edwards) (Brachyura, Grapsidae) under laboratory conditions. J. coastl. Res. 3: $63-70$

Epifanio, C. E., Masse, A. K., Garvine, R. W. (1989). Transport of blue crab larvae by surface currents off Delaware Bay, USA. Mar. Ecol. Prog. Ser. 54: 35-41

Forward, R. B., Buswell, C. U. (1989). A comparative study of behavioural responses of larval decapod crustaceans to light and pressure. Mar Behav. Physiol. 16: 43-56

Gore, R. H., Scotto, L. E. (1982). Cyclograpsus integer H. Milne Edwards, 1837 (Brachyura, Grapsidae): the complete larval development in the laboratory, with notes on larvae of the genus Cyclograpsus. Fish. Bull. U.S. 80: $501-521$

Haahtela, I. (1963). Some new observations and remarks on the occurrence of the mitten crab, Eriocheir sinensis Milne-Edwards (Crustacea, Decapoda), in Finland. Aquilo Ser. Zool. 1 9-16

Hinrichs, Grell, K. G. (1937). Entwicklungsstadien von Eriocheir sinensis, H. Milne Edwards, im Helgoländer Plankton. Zool. Anz. 119: 217-221

Hoestlandt, H. (1959). Répartition acteulle du crabe chinois (Eriocheir sinensis H. Milne Edwards). Bull. Fr. Piscicult. 194: 5-13

Ingle, R. W., Andrews, M. J. (1976). Chinese mitten crab reappears in Britain. Nature, Lond. 263: 638

Jensen, A. S. (1936). Den kinesiske uldhaandskrabbe (Eriocheir sinensis M.-Edw.) in Danmark. Biol. Meddr 13: $1-23$

Lee, T.-H., Yamazaki, F. (1989). Cytological observations on fertilization in the Chinese fresh-water crab, Eriocheir sinensis, by artificial insemination (in vitro) and incubation. Aquaculture 76: 347-360

Leloup, E. (1943). Contributions a l'étude de la faune Belge. XIII. La propagation du crabe chinois en Belgique pendant les années 1939-42. Bull. Mus. r. Hist. nat. Belg. 19: 1-4

Montú, M., Anger, K., de Bakker, C. (1990). Variability in the larval development of Metasesarma rubripes (Decapoda, Grapsidae) reared in the laboratory. Nerítica, Pontal do Sul, PR (Brazil) 5: 113-128

Nepszy, S. J., Leach, J. H. (1973). First records of the Chinese mitten crab, Eriocheir sinensis (Crustacea: Brachyura) from North America. J. Fish. Res. Bd Can. 30: 1909-1910

Otto, J. P., Kamps, L. F. (1935). Die chinesische Wollhandkrabbe in den Niederlanden, besonders in den Provinzen Groningen und Friesland. Zool. Anz. 110: 109-116

Panning, A. (1936a). Der Lebenskreislauf der Wollhandkrabbe. In: Zoologisches Staatsinstitut und Zoologisches Museum in Hamburg (ed.) Die chinesische Wollhandkrabbe in Europa. Der Fischmarkt 4/5, p. 4-8

Panning, A. (1936b). Wandern die Larven der Wollhandkrabbe? Zool. Anz. 115: 175-177

Panning, A. (1938). The Chinese mitten crab. Ann. Rep. Smithsonian Inst. 361-375

Panning, A. (1939). Die Larven von Eriocheir sinensis H. M.Edw. Zool. Anz. 125: 273-283

Peters, N. (1936). Die Verbreitung der Wollhandkrabbe in 
Europa. In: Zoologisches Staatsinstitut und Zoologisches Museum in Hamburg (ed.) Die chinesische Wollhandkrabbe in Europa. Der Fischmarkt 4/5: p. 2-4

Rosenberg, R., Costlow, J. D. (1979). Delayed response to irreversible non-genetic adaptation to salinity in early development of the brachyuran crab Rhithropanopeus harrisiz, and some notes on adaptation to temperature. Ophelia 18: 97-112

Sachs, L. (1984). Angewandte Statistik, 6th edn. Springer Verlag, Berlin

Sandifer, P. A., Smith, T I. J. (1979). Possible significance of variation in the larval development of palaemonid shrimp. J. exp. mar. Biol. Ecol. 39: 55-64

Schellenberg, A. (1928). Krebstiere oder Crustacea. II. Decapoda, Zehnfüßer. Die Tierwelt Deutschlands und der angrenzenden Meeresteile. Verlag Gustav Fischer, Jena

Schnakenbeck, W. (1933). Larven und erste Bodenformen. In: Peters, N., Panning, A. (eds.) Die Chinesische Wollhandkrabbe (Eriocheir sinensis H. Milne-Edwards) in Deutschland. Zool. Anz. Erg. Bd. zu 104: 157-170

Sulkin, S. D. (1984). Behavioral basis of depth regulation in the larvae of brachyuran crabs. Mar. Ecol. Prog. Ser. 15: $181-205$

Sulkin, S., Epifanio, C. (1986). A conceptual model for recruit-

This article was submitted to the editor ment of the blue crab, Callinectes sapidus Rathbun, to estuaries of the Middle Atlantic Bight. In: Jamieson, G. Bourne, N. (eds.) North Pacific Workshop on stock assessment and management of invertebrates. Can. spec. Publ. Fish. Aquat. Sci. 92: 117-123

Sulkin, S. D., Van Heukelem, W. (1982). Larval recruitment in the crab Callinectes sapidus Rathbun: an amendment to the concept of larval retention in estuaries. In: Kennedy, $V$ (ed.) Estuarine comparisons, Academic Press, New York, p. $459-475$

Thiel, H. (1936). Ist die Wollhandkrabbe ein Nahrungskonkurrent unserer Nutzfische? In: Zoologisches Staatsinstitut und Zoologisches Museum in Hamburg (ed.) Die chinesische Wollhandkrabbe in Europa. Der Fischmarkt 4/5: p. 8-11

Werner, H., SchmalfuB, H. (1936). Stoffliche Untersuchungen zur Verwertung der Wollhandkrabbe. In: Zoologisches Staatsinstitut und Zoologisches Museum in Hamburg (ed.) Die chinesische Wollhandkrabbe in Europa. Der Fischmarkt 4/5: p. 11-13

Yaroslaviseva, L. M., Naidenko, T Kh., Sergeeva, E. P., Yaroslavisev, P. V. (1986). Response to lowered salinity in the blue mussel Mytilus edulis from the Sea of Japan at different development stages. Biol. Mrya, Kiev 4: 40-47

Manuscript first received: December 3,1990 Revised version accepted: February 27, 1991 